\title{
Gifted Education in Switzerland: Widely Acknowledged, but Obstacles Still Exist in Implementation
}

VICTOR MUELLER-OPPLIGER ${ }^{1}$

$\approx$ With its strong federalism and direct democracy, as well as the high level of autonomy of its cantons, Switzerland does not have mandatory national policies and regulations on gifted education. Responsibility for the promotion of high-end learners is in the hands of the cantonal boards of education, and depends largely on their current professional understanding and educational-political foresight, as well as on the political volition and priorities of the school authorities. Within this diversity, there are schools with excellent concepts and successful implementations regarding gifted education, while other schools have a poor understanding of individualisation and potential-oriented learning. The present article summarises the philosophy and key aspects of a contemporary realisation of local- or regional-based integrated gifted education that is related to supplementary arrangements for special needs. Strengths and weaknesses in the identification and promotion of the talented within the Swiss school system are outlined and discussed.

Keywords: concepts of giftedness, federalism in gifted education, teacher education, identification, inclusive education, learning structures, national strategies/policies, the Swiss education system

1 University of Education and Teacher Training, Northwestern, Switzerland; victor.mueller@fhnw.ch 


\section{Izobraževanje nadarjenih v Švici: širše priznano, a pri implementaciji so še vedno težave}

Victor Mueller-OpPliger

$\approx$ Zaradi federalne oblike oblasti in neposredne demokracije ter visoke ravni avtonomije kantonov Švica nima obvezujoče nacionalne politike in pravil glede izobraževanja nadarjenih. Odgovornost za spodbujanje sposobnejših učencev je $\mathrm{v}$ odgovornosti sveta za izobraževanje $\mathrm{v}$ posameznem kantonu. Njihovo delovanje je odvisno od njihovega strokovnega razumevanja in izobraževalno-politične perspektive pa tudi od njihove politične volje in prioritet šolskih organov. V teh okvirih so šole, ki imajo zelo dobre koncepte in ki uspešno implementirajo izobraževanje nadarjenih, pa tudi takšne, ki slabo podpirajo individualizacijo in na razvijanje potencialov usmerjeno učenje. $\mathrm{V}$ prispevku so povzeti filozofija in ključne točke trenutnega uresničevanja lokalno ali regionalno zasnovanega integriranega izobraževanja nadarjenih, kot so urejeni v okviru posebnih potreb. Poudarjene in analizirane so močne in šibke točke $\mathrm{v}$ identifikaciji in spodbujanju nadarjenih $\mathrm{v}$ švicarskem šolskem sistemu.

Ključne besede: koncepti nadarjenosti, federalizem v izobraževanju nadarjenih, izobraževanje učiteljev, prepoznavanje, inkluzivno izobraževanje, izobraževalne strukture, nacionalne strategije/politike, švicarski izobraževalni sistem 


\section{National context and strategies}

\section{Political and educational structures in Switzerland}

In order to understand the educational situation in Switzerland, it is important to bear in mind that it is a small country of approximately 8 million people with a relatively high proportion of foreigners (23.8\%). Demographic trends are influenced by multilingualism, with a number of different languages being spoken in the country's four regions: German (64.9\%), French (22.6\%), Italian (8.3\%) and Rhaeto-Rumantsch (0.5\%). Some $21 \%$ of the population report using another main language in their families instead of, or in addition to, the four so-called national languages (BFS 2014).

Switzerland is a modern federal state marked by strong federalism and direct democracy. This is expressed in two ways: in the strong autonomy of the 26 cantons and their municipalities, and in their direct participation in political decision-making. However, it is not only the cantons that have a major influence on politics. As a result of the country's direct democracy, individual citizens also have a direct influence on the government via people's initiatives and referenda, with votes being held quarterly.

Within the confederation, the central government oversees specific national areas of responsibility, such as foreign, military and financial policy. A collective head of state, consisting of seven members, governs national affairs. The responsibilities and processes of education are coordinated in the federal department of economics, formation and research.

One of the functions of the Constitution is to link the various interests of the particular cantons with the overall interests of the federal state. Responsibility for education is predominantly in the hands of the cantons (with the exception of national university and vocational policies). Therefore, each canton has its own policies and regulations regarding education, which relate closely to the specific population's understanding of education.

While the main responsibility for education and culture lies with the cantons, the 26 cantonal ministers of education form a political board known as the Swiss Conference of Cantonal Ministers of Education (EDK), which undertakes coordination on the national level. Legally binding inter-cantonal agreements (known as concordats) form the foundation of the work of the EDK. Although the EDK coordinates the work of the cantonal boards of education, it nonetheless has a subordinated function: the prior legislative power is mostly rooted in the cantons (EDK, 2014). 


\section{Gifted education in Switzerland: Benchmarks and positions}

The education policies of all of the cantons declare in their charters the right of each student to be educated and fostered according to his/her individual abilities and possibilities. With these acknowledgements, they refer to the international declaration of Salamanca regarding the human right of individualised education (UNESCO, 1994).

In many schools, however, the reality is that teachers are mainly focused on teaching to the curriculum and the prescribed textbooks, some with more and others with less differentiation in their classes. For the majority of the population, there is a high national awareness of the importance of utilising all human resources, from the perspectives of national economics, the need for expertise, and sustainability. Nevertheless, there is a lack of mandatory policies on gifted education. Thus there is a clear discrepancy between most people's accurate assessment of the importance of expertise and high achievements, on the one hand, and the classroom routines in many schools, on the other, with their tendency to teach to an average level that should meet the needs of all students.

In the Programme for International Student Assessment (PISA), which aims to achieve a better understanding of the factors of effective teaching, the results of Swiss schools are above average in the ranking of high-end learning and high achievement; on the other hand, the results indicate very poor promotion of lower-end potential. PISA reveals that the Swiss school system produces an enormous heterogeneity of achievement (PISA, 2007). It also shows that Swiss schools are not sufficiently successful in overcoming sociocultural parenting. Moreover, Swiss schools often fail to consider the necessary compensation for students who are disadvantaged in a sociocultural sense. Too often, schools still fail to discover and appropriately foster giftedness of students who are foreign-language speakers or from families with a lower socioeconomic status.

The Swiss school system must intensify efforts to foster high-potential students with additional programmes over and above teaching to the average. At the same time, there is a need to improve the promotion of the strengths of all children at all levels in order to compensate for social discrimination. This process should be free of (historical) suspicions of reinstalling an elite socialclass system, but also of the erroneous assumption that individual differences and potentials should be disregarded in the interest of equal opportunities.

These aims contain not only organisational and economic aspects, but also sociopolitical and ideological expectations. This balancing act should be realised in so-called schools of variety and diversity. As schools of inclusion 
and integration, they should promote the gifted, while at the same time compensating for social disadvantages and raising the level of school achievement in general.

A contemporary foundation expresses the intentions of gifted education in a dynamic triarchic area of tension within anthropological, economic and ecological demands: “... the right of the person for self-realization, the benefit of human resources as intellectual and social capital of a society, and the aspect of sustainability in the meaning of qualification for life-long learning, reflected self-actualization and shared social responsibility" (Müller-Oppliger, 2014a, 58ff).

\section{Concepts of giftedness}

In general, Swiss schools follow the Three Ring Concept as a framework for understanding high achievement, in an interdependency of "above average ability", "productive creativity" and "task commitment" (Renzulli, 1978, pp. 18o184, p.261, 1986, pp. 53-92), as well as the Schoolwide Enrichment Model as a model for school development (Renzulli \& Reis, 1985, 1997). Some schools refer to the Triad Interdependence Model (Moenks, 1995), which is based on the Three Ring Concept and exemplarily shows the factors of the learning environment represented by school, peers and family.

Significantly, the Swiss understanding of these concepts follows the original understanding of Renzulli, who never defined his first ring as "intelligence", meaning an academic disposition that can be measured by intelligence tests. In his concept, Renzulli (1978) established the basis for so-called "multiple intelligences" (Gardner, 1983, 1999), and for an understanding of giftedness that is much wider than high academic-intellectual abilities. Unlike in earlier conceptions of giftedness, Renzulli also indicated the influences of the socialemotional environment. Already in his first concept (1978), he implemented the "houndstooth design" to his three rings, in order to show the interaction between personal potentials and environmental influences as dynamic factors in the development of high achievement.

The Munich model of giftedness (Heller, Hany, \& Perleth 1994) is also frequently used as a psychological model to understand the factors and catalysts of giftedness (mostly from school psychologists in the diagnostics of preconditions for giftedness).

In the last ten years, an increasing number of social- and pedagogicalbased models - such as the "actiotope model" (Ziegler, 2004), the "integrative model" (Fischer, 2006) and the "ecological model" (Mueller-Oppliger, 2009, 
2010, 2014b) - have emerged in addition to the more psychology-oriented models from the earlier days of gifted education. These new models function as frameworks for the pedagogical work of teachers and for schools on their way to developing teaching and learning methods, as well as educational structures, to foster the high-end abilities of students.

The definition of giftedness in Switzerland follows the definitions of the National Research Center on the Gifted and Talented (NRCGT), USA (Renzulli \& Reis, 1985) and the pentagonal theory of Sternberg and Zang (1995). Giftedness is defined as the potential for above-average achievement in relation to one's peers in terms of excellence, rarity, demonstrability, productivity and value criteria. The majority of educators, boards of education and cantons recognise giftedness under the dimensions of Gardner's “multiple intelligences”: musical, artistic, sports and social abilities are promoted as well as academic abilities. Very few school administrations continue to view gifted education from the one-sided perspective of academic and intellectual capabilities. Giftedness can refer to a single ability in a specific domain or it can cover multiple facets; it is not limited to cognitive aspects. In schools, we assume that $15-20 \%$ of students would be able to achieve more than school usually requires in various domains.

In response to these insights, nearly all Swiss cantons (with very few exceptions) have, over the last ten years, modified their policies relating to the identification of gifted students so that intelligence tests are no longer used exclusively, as they are no longer perceived as adequate for all of the various aspects and characteristics of giftedness (see chapter Identification: From "delegation" to "involvement").

\section{Structural elements and support}

\section{Cantonal policies and their coordination}

Following federal school organisation, all of the 26 cantons have, since 2000, developed their own policies for identifying giftedness and improving support for high-end learners (Grossenbacher, 2007, p. 37). Within the last few years, most cantons have also requested each individual school to indicate how it is defining the concept of giftedness and how it intends to recognise and foster gifted students. However, these concepts always depend on their authors or working groups: some of them are the result of collaboration with universities and expert panels, while others are more politically oriented. Each of these concepts reflects the expertise, knowledge, pedagogical understanding, socioeconomic foresight and political and financial will of the particular canton to 
fulfil the needs of the gifted. Due to the aforementioned direct democracy, the perceptions of the population regarding gifted education and its significance, as well as parents' power and other political influences, can have a strong impact on cantonal concepts of the promotion of the talented.

Within this loosely regulated system, there exist a variety of networks (e.g., the Working Group of EDK-East on Giftedness), cantonal workgroups, associations (such as the Parents Association of High-Ability Students), university training programmes (certificate and master's programmes for gifted education) and conferences (e.g., the Symposium-Begabung.ch, the annual Network-Symposium, and the International Congress for Gifted Education of the University for Education and Teacher Training of Northwestern Switzerland).

The national Network for Gifted Education of the EDK has an important role and influences the understanding of gifted education in the different cantons. This network is organised by the regional conference of German-speaking boards of education, and within it one finds delegates from each canton, from universities and teacher training colleges with expertise and special competencies in gifted education, and from a support and counselling institution in the field.

This partly national network coordinates efforts, discussions and developments in the various cantons. The outcomes and policies within particular cantons, and the actual needs of schools that are in the process of becoming schools of inclusion, are discussed and reflected on, as are contemporary concepts and new approaches from research and global developments in giftedness, which are introduced by the delegates from universities of education and teacher training.

In addition to an annual symposium, meetings organised each term ensure that knowledge related to gifted education can be propagated and reflected on nationwide for the benefit of teachers, principals and superintendents, as well as interested members of school boards. From time to time, the Network for Gifted Education publishes a report on nationwide school development and improvements. The last report, entitled "Gifted Education - No Longer a Taboo" (SKBF/CSRE, 2007), appeared in 2007.

\section{A systemic approach: Gifted education claims school development}

The national network views gifted education as a systemic approach (Grossenbacher, 2007, p. 37). On the one hand, gifted education means the development of teaching practices in classrooms, while, on the other hand, it 
involves reflection on traditional learning structures, making them more flexible, as well as the improvement of schools as learning and profiling institutions based on their individual resources.

The network postulates that gifted education is initially located in the classroom, where integrative but at the same time individualised resourceoriented learning processes take place. "Inner differentiation" offers a learning environment where students can learn in their individual "zone of proximal development" (Vygotsky, 1978), with different methods and learning styles, in their own time, and with a personal learning plan (including individual learning aims with differentiated degrees of depth in addition to the core curriculum). In such learning contexts, students often maintain their own personalised portfolios and learning journals, which contain learning products as well as metacognitive reflections on their learning processes, strategies and attitudes (Purcell \& Renzulli, 1998; Eisenbart, Schelbert, \& Stokar, 2010; Mueller-Oppliger, 2013). However, this concept also requires competencies on the part of the teachers in terms of process-based pedagogical learning diagnosis, in order to discover possible potentials in the students' achievements and behaviours (Netzwerk Begabungsförderung, 2013, p. 18; Mueller-Oppliger, 2014C, p. 208).

For students who could achieve more than these classroom learning environments allow, schools often offer additional local programmes aimed at fostering high-ability learners: pull-out programmes, special "resource rooms" (rooms with structured high-end learning material for additional discovering, research-based or problem-based learning), participation in competitions, and early studies at some universities for older students. These additional learning arrangements are led by qualified teachers who are trained to meet the needs of gifted learners. The schools carry them as a community. Regulations for identification, coordination between classroom and additional learning activities, further education/sensitising, and differentiation for all teachers, as well as a transparent organisation of responsibilities, are the key challenges for these schools.

At a superior level, individual cantons or regions are responsible for regulations and policies, as well as for funding appropriation. Cantons can organise special offices to promote gifted education, or for counselling schools, teachers and parents. Often, cantons have the power to decide on the provision of programmes for the further education of the teachers, or for their (financial) support.

Along with these systemic approaches, there are certain "pillars" of gifted education in accordance with the nationally accepted Schoolwide Enrichment Model (Renzulli \& Reis, 1997; Müller-Oppliger, 2014d, p. 252), such as 
acceleration (in-class and cross-class), enrichment (in-class and supplemental), curriculum compacting of learning times, pull-outs and ability grouping, as well as mentoring for special or superior abilities that individual schools cannot promote. An increasing number of schools are implementing individual talent portfolios and development journals for all students.

\section{Identification: From "delegation" to "involvement"}

At the end of the last century, gifted students were primarily identified by testing their intelligence, with testing largely being executed by school psychologists. As a result, recognition of giftedness was delegated, while teachers were absolved from this responsibility and their expertise was disregarded: giftedness became a special psychological status. Over the last ten years, a better and more elaborated understanding of high achievement and its various conditions has encouraged nearly all cantons to transform their procedures into much more differentiated practices: teacher recommendations and the involvement of parents, as well as the possibility of self-nomination, are integrated into multi-perspective procedures. These procedures are often guided by specialists for gifted education (see next chapter) in their schools, in collaboration with the school psychologist, who helps to deal with children's personal issues, underachievement or twice exceptional in contexts requiring the expertise of a psychologist. Individual schools do not employ psychologists, but they are available from the canton.

This progression goes hand in hand with a basic re-involvement of classroom teachers and the requirement for all teachers to have advanced competencies in dynamic and learning process-orientated pedagogical diagnosis.

There are several scales and questionnaires available to teachers with indicators of different aspects of giftedness and students' attitudes. Most of them are originally based on the research and expertise of the NRCGT. In fact, the majority of identification processes employed in Switzerland are based on the recommendations and framework of the NRCGT (Renzulli \& Reis, 1997).

In accordance with, and as a continuation of, these widely accepted concepts, screening has been developed within the last few years at the Pedagogical University of Northwestern Switzerland (PH FHNW). As well as data from classroom achievements, this model includes teachers' recommendations, parents' statements and an InterestAlyzer for children. Moreover, it contains testing in thinking and learning styles, culture fair intelligence sections, and aspects of student motivation and self-concept. Typically implemented in third grade classes, screening is conducted by qualified experts in gifted education 
(master's programme), in consultation with teachers and other persons involved in the learning processes of the student.

\section{Further education for teachers: A need}

Since 2004, teachers have had an opportunity to improve their competencies by attending post-diploma studies in the field of gifted education and talent development. Two pedagogical universities in Switzerland offer Certificates of Advanced Studies (CAS following the regulations of Bologna) in gifted education. Subsequent to the CAS, the University of Education and Teacher Training of Northwestern Switzerland (PH FHNW) has, for the past ten years, run a master's programme (Master of Advanced Studies) in integrative gifted education, which is accredited by the Swiss Conference of Cantonal Ministers of Education. The master's programme is connected to the University of Connecticut with its National Research Center on Gifted Education, and to certain programmes of other universities in German-speaking nations that work with the online courses of the PH FHNW.

Over the last ten years, the PH FHNW has become a leading institution and well-known competence centre for further education in gifted and talent development in German-speaking Europe. During this time, 290 teachers have obtained certificates or master's degrees in gifted education. These experts are likely to have a significant impact on the direct transfer of expertise on gifted education in schools, as well as influencing boards of education that are responsible for policies.

With these nationally and internationally acknowledged study programmes, Switzerland is well placed with regard to the further education of teachers. A major problem, however, is the lack of coordination in Switzerland regarding both the financing of these studies and additional rewards for the specific functions of graduates as experts in gifted education.

\section{Research and development in the field}

In Switzerland, there is a lack of research in gifted education because there is no chair or institute of a university specifically devoted to gifted education and talent development. Some research has been done within the framework of a long-term study of early readers and children with early mathematics abilities and their development through to their vocational achievements (Stamm, 2005, 2007), while other research has focused on the neuropsychological aspects of underachievement and ADHS (Gyseler, 2009). Reports of the 
Swiss Network (Grossenbacher, 1999, 2007) function as a kind of comparative study of the situation in schools, and Tettenborn and Tanner (2013) were commissioned by the network to conduct research on how teacher training prepares young teachers for gifted education. Recent research has focused on: the situation regarding gifted education in gymnasiums, colleges and universities; the issue of financing the development of excellence on these levels by the state or in cooperation with foundations and other institutions (Mueller-Oppliger, 2013); and the implementation of individualised learning architectures for the inclusive fostering of giftedness (IBFLA) in schools (Dinkelacker, Kirchgässner, Müller, \& Müller-Oppliger, 2014).

Furthermore, a number of relevant school developments, gifted programmes and teaching materials have been created. These are theory-based and have been reported and reflected on scientifically. In addition, there are more than 200 master's theses on specific aspects, implementations, school developments or evaluations of programmes in the field of gifted education.

The sometimes criticised gap in basic research by individual researchers is compensated by close connections and active participation within the international research and scientific community. The collaboration of the master's programme with the National Research Center on Gifted and Talented in the US, its involvement in the IPEGE (International Panel of Experts in Gifted Education) and the IRATDE (International Research Association for Talent Development and Excellence), its partnership in the EU-Comenius project eVOCATIOn, as well as its active participation within the WCGTC (World Conference on Gifted Children) and the ECHA (European Council for High Ability) ensure that the programme is part of contemporary research and scientific contexts and discourse.

\section{Financial aspects and regulations}

In Switzerland - as in many other nations - programmes for gifted education currently suffer from the global reduction in investments in special services. Nevertheless, the majority of cantons have changed their finance regulations from exclusive low-end promotion to a pool solution that enables schools to finance special needs at both ends of the spectrum. Individual schools are empowered to decide how to allocate the contributions effectively for the special needs of its students (ranging from learning and behavioural deficits to the promotion of the gifted). There are, however, two problems associated with this new regulation. Firstly, the total amount of funding for all special needs (from the handicapped to the gifted) is largely used as it was before, i.e., primarily 
for low-end capabilities. This means that, although gifted education has a right to financial support, this support is not regularly provided because it shortens other needs. Secondly, many teachers and principals are still focused on the promotion of the disadvantaged, and often fail to act in both directions. Financial support for gifted education differs from canton to canton: ranging from the credit of four lessons per hundred students in a school pool to the discontinuation of the contribution for economic reasons.

Further education for teachers, in the form of courses, is regularly supported. Less satisfying is the fact that certificates and master's studies in gifted education are promoted very differently: there are cantons and schools that pay the tuition fees for some of their teachers to obtain the necessary expertise in their schools, and others where teachers have to pay nearly all of the fees themselves.

Contests and other special programmes for gifted education can often not be realised without essential support by foundations. As a tendency, it is noticeable that when public funds become increasingly restricted, special programmes for gifted education end up being economically dependent on others (which is not entirely unproblematic).

\section{Strengths, weaknesses and opportunities}

\section{Strengths and positive features}

\section{Great flexibility for innovative schools}

Gifted education is becoming increasingly established in the awareness of schools and of the population in general. The activities of recent years related to gifted education have also had an impact on the current discussion on heterogeneity, diversity and inclusion in schools. Having initially started at the primary school level, today there are schools on all levels paying attention to this aspect of education, including kindergartens and gymnasiums.

Within the framework of various policies, in most cantons individual schools have a relatively wide scope to initiate and realise gifted education. This is part of direct democracy and the federal system, as well as reflecting an understanding that schools should be strongly rooted in their communities. One should not, of course, forget that limits are created by the guidelines of the cantons with their particular political will. It is, however, important to note that the strength of direct democracy can also be a handicap in a region, canton or school where those responsible for education, or the teachers themselves, fail to recognise the necessity of gifted education or lack the necessary professional 
knowledge in this regard. On a positive note, we can state that schools with expert knowledge, with the will to develop gifted education, and with a team of teachers whose persuasion is matched by the commitment of its local school board, have the power and possibilities to develop excellent gifted education programmes. This applies to the majority of cantons; there are very few cantons where this is restricted by cantonal policies or funding restraints.

\section{Efforts in the development of individualising and strength-oriented learning environments}

As another strength, we can see that the majority of faculties and professors at pedagogical universities are investing a great deal of effort in the development of inner differentiation in learning environments. Individualisation has - along with cooperative learning as its complement - become a criteria for qualified teaching. Not least, this is possible because Switzerland has formulated "minimal standards" in its core curriculum. This means that, beyond the fulfilment of these minimal standards, there is an open range for individualisation, where students can distinguish themselves in their strengths. This is a challenge for the currently emerging "Curriculum 21" (the new and first curriculum that will be valid for the majority of German-speaking cantons).

\section{Multi-perspective personalised identification}

A very positive fact is that the identification process has changed in nearly all cantons, going beyond the IQ as the exclusive determining factor to much more sophisticated processes of a multifactorial and more holistic perception of giftedness. Teacher recommendation, parental involvement and, in many schools, the possibility of student self-nomination are the results of a more systemic and person-orientated view of the identification and formation of giftedness and high achievement, taking into account individual potentials, personal traits, self-direction and self-responsibility. The selection procedure is guided by specialised gifted coordinators - where available - in consultation with classroom teachers.

\section{Further education for teachers with high international standards}

For more than ten years, Switzerland has had certain regional programmes for the further education of teachers in gifted education, as well as a nationwide Master of Advanced Studies programme to qualify teachers and school leaders. The master certification is accredited by the Swiss Conference of Cantonal Ministers of Education and meets the European standards of Bologna. In order to assure high quality, the programme is under the continuous 
monitoring of the international community (NRCGT, IPEGE, IRATDE, ECHA and WCGTC), as well as being engaged in an ongoing process within relevant international research communities. In 2014, the programme organised an international congress on gifted education with more than 70 workshops and 750 participants from Switzerland and abroad.

\section{A permeable education system for lifelong development and improvement}

In addition to "academic giftedness" in the school branch that is typically associated with university attendance, Switzerland has for many years operated distinguished and elaborated vocational education. Supplementing the traditionally highly standardised vocational education, an array of extended options have been developed in recent years, particularly in the voc-tech, social and health spheres, which in earlier days did not depend on university degrees. The transition between vocational education and academic further education has been facilitated and structured. Building from many vocational apprenticeships, one can today achieve access (Mature, Baccalaureate) to a university of applied sciences, or to another university, via the so-called "passerelle" (skywalk). There is increasing recognition that these other kinds of secondary schools, apprenticeship programmes and tertiary institutions of various types are an alternative path, and are enabling gifted youngsters to change tracks at various stages of their life. High-quality apprenticeship programmes are widespread and can lead to further education and academic studies later in life as well.

\section{Weaknesses}

\section{No national obligation to promote high ability and expertise}

The advantage of increased openness and recommended opportunities for individual schools (labelled as "partly autonomous conducted schools") may, at the same time, be a weakness. Although there is potential for major developments, they have to be initiated and realised by dedicated teaching teams and principals in coordination with their local school authorities. Gifted education sometimes appears patchy. Since there is a lack of national policies on promoting the gifted, everything depends on the understanding, involvement and competencies - as well as the political priorities - of local or cantonal authorities and school teams. This is also true regarding issues such as whether a school has a gifted pull-out programme and/or a gifted coordinator on the staff. In some cantons, gifted programmes and other activities for gifted students originate from the "bottom up": they are initiated through teachers, parents or 
principals. Other cantons require that their schools fulfil demanding standards regarding the promotion of all students in their individual potentials.

\section{The handicap of a pre-structured middle school}

Generally, lower secondary education (grades 7-9) is, in many places, a problem for some aspects of gifted education, because these classes are still sorted into three types of school levels (or programmes within schools), and children's entry into one or another of these branches is often primarily based on grades received from their classroom teachers in primary school. The general public, as well as many teachers, do not seem to be worried about the subjectivity and non-comparability of teacher-given grades and recommendations, although there is overwhelming research on biases in the validation of students' achievements (Kronig, 2007).

In many schools, there is still a general belief that gifted children get good grades and therefore earn admission to a gymnasium, and consequently also to a university. It is therefore still widely believed that the basic structure and traditional sorting mechanisms "handle the gifted challenge appropriately". Apart from being rather deterministic, this attitude also assumes that the regular university-prep curriculum is the right way to educate gifted children in general, which may be far from the truth!

\section{Deficient awareness of the disadvantaged}

This brings us back to the PISA (2007) results for Swiss schools, which show that, in too many places, social background still too often determines the school career. Whether or not a given high-ability child finds him or herself a suitable programme of independent study, enrichment, mentoring, etc. seems to depend to a considerable degree on where he or she lives and what the staff in his or her school have chosen to do, as well as on whether the school has competent specialists, personnel support, teacher teams, etc. Often, parents initiate the screening of their child, but (like elsewhere) this tends to give greater opportunities to the (gifted) children of educated, motivated, prosperous families (encouraging parents) than to those of poor, immigrant or otherwise disadvantaged families. The latter group of children are more or less dependent on the knowledge and motivation of the staff in their schools.

Unlike other nations, Switzerland does not have special policies for the promotion of minorities and the elimination of discrimination in schools. Compensation for social disadvantage and the promotion of children from less educated families is on the rise, but this has not yet led to specific programmes for those who are both gifted and disadvantaged. 


\section{Little motivation for high achievement}

Compared to other school systems, in terms of policies, Swiss schools offer little motivation for the demonstration of special achievements within regular schools. Scholastic marks, with the consequent approval for entry to the one or another continuing school, are the only stimulus. There are no bonuses, no special diploma or announcements related to special achievements, and less social recognition, not to mention an absence of financial support for special efforts. In a way, there seems to be a cultural disinclination to talk about some children being more capable than others, and considerable fear about "elitism". The tendency is to offer all pupils equality rather than equity in being fostered to their full potential.

The low level of interest in high achievement also has negative consequences when it comes to families with income power and high expectations making use of their right to educate their children in private schools. Private schools are expanding in Switzerland, slightly more notably in high-income areas and on the part of foreign parents with high social status. This trend brings a risk of undermining solidarity, or even causing deterioration, when it gets to the point that more high-income parents take their children out of public school due to their higher aspirations. Private schools are perceived as being more flexible and efficient in the realisation of requirements.

Despite the criticism, there are, of course, many classes and schools with excellent learning and acknowledgement cultures, and teachers who are able to inspire their students to high achievement and to instil in them the will to achieve to their full potential. These teachers and schools often work with portfolios for each student and invest special efforts in learning coaching. They know that success in lifelong learning and achievement demands personal cocognitive traits, self-confidence and a belief in self-efficacy, as well as in executive competencies that are not gained only by scholastic marks.

\section{Lack of evaluation of the effectiveness of gifted programmes}

Many gifted programmes do not evaluate their effectiveness on basis of the individual student. Increasingly, evidence of individualisation is required within wider school evaluation with external experts (following the intention to develop schools of inclusion). However, these school evaluations are often quantitatively oriented and are not designed to demonstrate individual effects and conditions of success on the particular gifted student. Additional micro-analyses of the learning processes of gifted students would increase the understanding of the personal and contextual factors that provoke either high achievement, indifference or underachievement. It would provide the school 
system, the individual school and teachers with an opportunity to optimise learning processes based on personal conditions and potentials.

\section{Financial support is weak and partly insufficient}

Due to the absence of national policies on gifted education, funding depends on the distribution of resources from the cantons to the schools, a process that is strongly influenced by the economics and current political priorities of local or cantonal authorities. In many cantons, financing the qualification of expert teachers in gifted education is an unresolved problem. On the one hand, further education studies are accredited by the Swiss Conference of Cantonal Ministers of Education and, as has been proven, schools and cantons are requesting many more experts than can be trained; on the other hand, the sourcing of these studies is only partially provided in some cantons. Often, the teachers involved have to partly cover the study fees themselves, despite fulfilling functions required by the school. Moreover, based on their advanced competencies, gifted education specialists fulfil key functions in their schools with no additional financial incentive.

\section{Opportunities}

Despite the need for ongoing efforts regarding gifted education, some promising developments can be observed within the context of the education system. One of them is the development of the new (almost nationwide) competency-based "Curriculum 21", which includes competency frames to indicate the achievements of students between minimal and excellent standards. The new competency grids can fulfil the function of individualised fostering plans, showing progress and actual learning improvements, as well as above-average and excellent achievements. They show individual profiles of the students, and can serve as basis for individualised learning agreements.

In recent years, some cantons and cities have developed special programmes in addition to the pull-out programmes in the individual schools. These include: regional learning centres for the gifted in the canton Aargau, with "Atelier Litera", "Atelier Historia", "Mathsupport", "Robotic" and others (www.ag.ch); the "Universikum" in the canton Zurich, with special courses for the gifted (www.stadt-zuerich.ch/universikum), including summer camps for gifted students; and the "Exploratio" in Winterthur (schule.winterthur.ch), as an additional offering for high achievers.

Meanwhile, most universities in Switzerland have arranged and are open for early studies for scholars who are willing and able to commence 
their university studies early in addition to attending their regular gymnasium school programme.

The foundation for gifted children makes another kind of resource available with its well-known free counselling for parents who are seeking help regarding special abilities and the promotion of their children.

In the field of teaching and learning development, the canton Aargau is realising a joint research project in cooperation with the PH FHNW to develop learning architectures for the stimulation of high achievement in classes of inclusive learning. The joint development of learning and teaching environments and teaching behaviours on the part of schools in cooperation with universities for teacher training seems to be a sustainable setting to improve both practices in the professional field as well as theoretical discourse on the possibilities of and obstacles to scholastic education.

Furthermore, national contests such as "Schweizer Jugend forscht" (http://sjf.ch/) with "kids@science” and "Girls Science” for children aged 10-13 years, as well as the "Swiss Talent Forum" and its study weeks, have an impact on the fostering of high achievement in Switzerland.

Of particular note within the context of school competitions is the LISSA Award (www.lissa-preis.ch). Schools with elaborated programmes in gifted education, with substantiated long-term school development, with impact on other schools, and with continuous evaluation are ranked and rewarded by a jury of experts in gifted education. The particular effect of this award is that, in addition to the contest, the development processes and best practices of successful schools are documented and published for use by other interested schools, teachers or principals. From time to time, the foundation for gifted children that runs the LISSA Award produces video documentation of the awarded schools, in order to share their efforts and outcomes within the profession. This kind of modelling seems to be an encouraging method to motivate other school teams and school leaders.

\section{Conclusion}

Despite the lack of mandatory national policies on gifted education and the absence of a national strategy, there is a reflected awareness of the significance of gifted education in some cantons. The majority of cantons have developed concepts in this regard and require specific implementations from individual schools. However, there are still a few cantons that have failed to assimilate these requirements, which is hard to understand, as Switzerland is a nation whose economy relies solely on the knowledge, innovations, excellence and expertise of its population. 
Instead of national regulations, Swiss school development is led by agreements and conventions mostly between cantons or within specialised and mandated networks. Although this works well, it is highly dependent on the current professional understanding, educational-political foresight, and political volition of cantons or school districts. This also results in ongoing controversy about the needs and significance of educational provisions, which, although preventing unreflective routines, requires a great deal of ongoing efforts of persuasion.

Numerous subsidiary actors support gifted education in action fields where the state does not fulfil the necessities. On the one hand, this solidarity relieves the obligations of the state, while, on the other, it compensates for a failure to fulfil obligations that are considered to be the duty of a national school system, i.e., to ensure the social and economic welfare of the nation.

There is an discrepancy between the necessity and urgent demand for experts and specially trained teachers for gifted education, and the absence of support for advanced studies and/or the absence of rewards for the special function that these specialised teachers fulfil.

Many schools have perceived the signs of the time and the changes in education. They are aware of the need to improve the conditions for fostering excellence and high achievement, as demanded by the configuration of a challenging future. These schools invest a great deal of effort in making learning structures more flexible, and in the development of individualised learning environments with differentiated learning paths to the benefit of the students and their strengths, and of potential-oriented learning. Sometimes, the impetus comes from cantonal policies or assignments, sometimes from parents, and very often from dedicated and deeply committed teachers and school leaders.

\section{References}

BFS. Bundesamt für Statistik. (2014). Sprachen, Religionen - Daten, Indikatoren. Retrieved July 1 2014 from http://www. bfs.admin.ch/bfs/portal/de/index/themen/o1/o5/blank/key/sprachen.html EDK. (2014). Swiss Conference of Cantonal Ministers of Education. Portrait of the Swiss Conference of Cantonal Ministers of Education (EDK). Retrieved July 12014 from http://www.edudoc.ch/static/ web/edk/port_edk_e.pdf

Eisenbart, U., Schelbert, B., \& Stokar, E. (2010). Stärken entdecken - erfassen - entwickeln. Das Talentportfolio in der Schule. Bern: Schulverlag plus AG.

Fischer, C. (2006). Lernstrategien in der Begabtenförderung. Eine empirische Untersuchung zu Strategien selbstgesteuerten Lernens in der individuellen Begabungsförderung. Habilitationsschrift. Universität Münster.

Gardner, H. (1983). Frames of Mind. The Theory of Multiple Intelligences. New York: Basic. 
Gardner, H. (1999). Intelligence Reframed: Multiple Intelligences for the 21st Century. New York: Basic. Grossenbacher, S. (2007). Bestandesaufnahme I: Massnahmen der deutschschweizerischen Kantone zur Begabungsförderung. In SKBF/CSRE (Hrsg.), Begabungsförderung - kein Tabu mehr. Aarau:

Schweizerische Koordinationsstelle für Bildungsforschung; Trendbericht 11.

Grossenbacher, S. (Hrsg.) (1999). Begabungsförderung in der Volksschule. Aarau: Schweizerische Koordinationsstelle für Bildungsforschung; Trendbericht 2.

Gyseler, D. (2009). Hochbegabte Minderleistende: Erkenntnisse aus der Hirnforschung. Journal der

Schweizerischen Gesellschaft für Begabungs- und Begabtenförderung, 2/1, 5-10.

Heller, K. A., Perleth, Ch., \& Hany, E. A. (1994). Hochbegabung - ein lange Zeit vernachlässigtes Forschungsthema. Einsichten - Forschung an der Ludwig-Maximilians-Universität München, 1. Kanton Aargau. Departement Bildung, Kultur und Sport. Retrieved July 22014 from https:// www.ag.ch/de/bks/kindergarten_volksschule/besondere_foerderung/begabungsfoerderung/ begabungsfoerderung.jsp

Kronig, W. (2007). Die systematische Zufälligkeit des BiIdungserfoIgs. Theoretische Erklärungen und empirische Untersuchungen zur Lernentwicklung und zur Leistungsbeurteilung in unterschiedlichen Schulklassen. Bern: Haupt Verlag.

LISSA-Preis. Begabungen machen Schule. Retrieved July 22014 from http://www.lissa-preis.ch/ Mönks, F. J. (1995). Hochbegabung - ein Mehrfaktorenmodell [High Ability - The Model of Triadic Interdependence]. Grundschule, 28, 15-18.

Müller-Oppliger, V. (2009). Impulse zu Begabungsmodellen und Menschenbild - Ein dialektisches Begabungsmodell. Gadheimer Kreis: Frankfurt a.M.: Karg Stiftung. Müller-Oppliger, V. (2011). (Hoch-)Begabung in pädagogischem Bezug zum Menschenbild. Paradigmenwechsel zu einem dialektischen Begabungsmodell. In G. Weigand, A. Hackl, \& O. Steenbuck (Hrsg.), Werte schulischer Begabtenförderung - Begabungsbegriff und Werteorientierung (pp. 55-69). Frankfurt am Main: Karg-Stiftung.

Müller-Oppliger, V. (2013). Portfolio - ein Kernelement der Begabungs- und Begabtenförderung. Erkennen von Potenzialen und Fähigkeiten aufgrund reflexiver Auseinandersetzung mit individuellen Leistungen und Lernwegen. In P. H. Steiermark (Hrsg.), Verborgen? Versteckt? Entdeckt! Begabungen entdecken, fördern und nutzen. Graz: Leykam-Studienverlag. Müller-Oppliger, V. (2014a). (Hoch-)Begabtenförderung im Spannungsfeld von Anthropologie, Ökonomie und Ökologie. In G. Weigand, V. Müller-Oppliger, A. Hackl, \& G. Schmid (Hrsg.), Personorientierte Begabungsförderung (pp. 60-70). Weinheim, Basel: Beltz Verlag. Müller-Oppliger, V. (2014b). Paradigmenwechsel zu einem ökologischen Begabungsmodell. In G. Weigand, V. Müller-Oppliger, A. Hackl, \& G. Schmid (Hrsg.), Personorientierte Begabungsförderung. Eine Einführung in Theorie und Praxis (pp. 70-79). Weinheim, Basel: Beltz Verlag. Müller-Oppliger, V. (2014c). Portfolio. Ein Element personalisierter Begabungsförderung. In G. Weigand, V. Müller-Oppliger, A. Hackl, \& G. Schmid (Hrsg.), Personorientierte Begabungsförderung (pp. 194-210). Weinheim, Basel: Beltz Verlag.

Müller-Oppliger, V. (2014d). Das „Schoolwide Enrichment Model“ als Choreografie inklusiver 
Begabungs- und Begabtenförderung. In G. Weigand, V. Müller-Oppliger, A. Hackl, \& G.

Netzwerk Begabungsförderung. (2013). Erfordernisse und Perspektiven für wirksame

Begabungsförderung. Aarau: BKSD.

PISA-Konsortium Deutschland. (Hrsg.) (2007). PISA 2006. Die Ergebnisse der dritten internationalen

Vergleichsstudie. Münster: Waxmann Verlag.

Purcell, J. H., \& Renzulli, J. S. (1998). Total Talent Portfolio. A Systematic Plan to Identify and Nurture Gifts and Talents. Mansfield, CT: Creative Learning Press.

Renzulli, J. S. (1978). What Makes Giftedness? Reexamining a Definition. Phi Delta Kappan, 6o, $180-184,261$.

Renzulli, J. S. (1986). The Three-Ring Conception of Giftedness: A Developmental Model for Creative Productivity. In R. J. Sternberg \& J. E. Davidson (Eds.), Conceptions of Giftedness (pp. 53-92). New

York: Cambridge University Press.

Renzulli, J. S., \& Reis, S. M. (1985). The Schoolwide Enrichment Model: A Comprehensive Plan for Educational Excellence. Mansfield Center, CT: Creative Learning Press.

Renzulli, J. S., \& Reis, S. M. (1997). The Schoolwide Enrichment Model: A How-To Guide for Educational Excellence. Mansfield Center, CT: Creative Learning Press.

Schule Winterthur. Retrieved July 22014 from http://schule.winterthur.ch/foerderangebote/ exploratio/

Schweizer Jugend forscht. Retrieved July 22014 from http://sjf.ch/

SKBF/CSRE. (2007). Trendbericht 11. Begabungsförderung - kein Tabu mehr. Bilanz und Perspektiven.

Aarau: Schweizerische Koordinationsstelle für Bildungsforschung.

Stamm, M. (2005). Zwischen Exzellenz und Versagen. Schullaufbahnen von Frühlesern und

Frührechnerinnen. Zürich: Rüegger.

Stamm, M. (2007). Begabtenförderung und soziale Herkunft. Befunde zu den verborgenen

Mechanismen ihrer Interaktion. Zeitschrift für Soziologie der Erziehung und Sozialisation, 27(3), 227-242.

Sternberg, R. J., \& Zang, L. S. (1995). What Do We Mean by “Giftedness"? A Pentagonal Implicite

Theory. Gifted Child Quarterly, 39(2), 88-94.

Tettenborn, A., \& Tanner, S. (2013). Untersuchung zum IST-Zustand der Vermittlung von

Kompetenzen im Bereich der Begabungs- und Begabtenförderung in der Lehrerinnen- und

Lehrerbildung (Primarstufe) der Deutschschweiz. Forschungsbericht der Pädagogischen Hochschule Luzern im Auftrag des Netzwerks Begabungsförderung Schweiz.

UNESCO. (1994). The Salamanca Statement and Framework for Action on Special Needs Education. Adopted by the World Conference on Special Needs Education: Access and Quality, Salamanca, Spain, 7-10 June 1994.

Universikum-Kurse. Retrieved July 22014 from https://www.stadt-zuerich.ch/universikum Vygotsky, L. S. (1978). Mind in Society: The Development of Higher Psychological Processes.

Cambridge, Mass.: Harvard University Press.

Ziegler, A. (2004). The Actiotope Model of Giftedness. Ulmer Forschungsberichte aus der Pädagogischen Psychologie. University of Ulm. 


\section{Biographical note}

Victor Mueller-OpPliger has been a teacher and school principal, grade 3 to 9, during more than 12 years before he became a professor at the University of Education and Teacher Training of Northwestern Switzerland (PH FHNW). Studies in Special Education and Educational Psychology. Research in «gifted education and talent development», «identification of gifted», «self regulated learning», «learning architectures for differentiated and selfdirected learning», «coaching and mentoring in learning processes».

Program director of the international Master study program in «Integrative Education of Gifted and Talent Development IBBF» of PH FHNW in cooperation with the University of Connecticut.

Profile: http://www.fhnw.ch/personen/victor-mueller 